\title{
Future precipitation patterns in the Lake Victoria Basin using CMIP6 projections
}

Obed M. Ogega ${ }^{\mathrm{a}, \mathrm{b}}$, Enrico Scoccimarro ${ }^{\mathrm{c}}$, Hussen S. Endris ${ }^{\mathrm{d}}$, Maurice Nyadawa ${ }^{\mathrm{e}}$, James Mbugua ${ }^{\mathrm{f}}$, and Herbert Misiani ${ }^{\text {d }}$

${ }^{a}$ School of Environmental Studies, Kenyatta University, Nairobi, Kenya

${ }^{\mathrm{b}}$ Programmes, The African Academy of Sciences, Nairobi, Kenya

${ }^{\mathrm{c}}$ Fondazione Centro Euro-Mediterraneo sui Cambiamenti Climatici, 40127 Bologna, Italy

${ }^{\mathrm{d}}$ IGAD Climate Prediction and Applications Centre, Nairobi, Kenya

eSchool of Engineering and Technology, Jaramogi Oginga Odinga University of Science and

Technology, Kisumu, Kenya

${ }^{\mathrm{f}}$ Coastal Oceans Research and Development - Indian Ocean (CORDIO) East Africa, Mombasa, Kenya

Corresponding author: Obed Ogega (obed.matundura@gmail.com)

\section{Abstract}

In late/early 2019/2020, unprecedented high-water-levels were observed in Lake Victoria causing massive flooding in the low-lying lake-adjacent areas and disrupting human and natural systems in the Lake Victoria Basin (LVB). The high lake water-level coincided with unusually heavy and prolonged 2019 June to December precipitation in the LVB. The current study estimates future precipitation patterns over the LVB using HighResMIP and ScenarioMIP general circulation model (GCM) simulations from the $6^{\text {th }}$ phase of the Coupled Model Intercomparison Project (CMIP6). Results show that HighResMIP and ScenarioMIP simulations can adequately reproduce LVB's precipitation patterns - albeit with location-specific biases. Generally, the GCM simulations tend to over-estimate precipitation patterns over Lake Victoria while under-estimating precipitation patterns over the lake-adjacent areas. Projections show significant future precipitation changes over the LVB relative to the 1970-1999 baseline, with more pronounced changes over the lake than in lake-adjacent areas. Overall, mean annual precipitation is projected to increase by about $18 \%$ and $31 \%$ by the end of the century, under SSP2-4.5 and SSP5-8.5 scenarios, respectively. Additionally, mean daily precipitation intensity (SDII) is projected to increase by upto $14 \%$ while the maximum 5-day precipitation values (RX5Day) increase by up-to 71\% under the SSP5-8.5 scenario. Heavy precipitation events, represented by the width of the right tail distribution of precipitation (99p-90p), are projected to increase by 50\% and 94\% under SSP2-4.5 and SSP5-8.5, respectively. Given that direct precipitation accounts for about $80 \%$ of Lake Victoria's water budget, the lake's future water-level fluctuations are likely to be more rampant and unpredictable under the changing climate. Hence, enhanced production and use of climate services is recommended to minimize the risk posed by potentially high water-level fluctuations in Lake Victoria and, ultimately, enhance the socio-economic safety of communities in the LVB.

\section{Keywords}

CMIP6, HighResMIP, ScenarioMIP, Lake Victoria, Climate change, East Africa 


\section{Introduction}

During late 2019 and early 2020, unprecedented high lake water-levels were observed in Lake Victoria, resulting in massive flooding in the lake-adjacent areas (Mafaranga, 2020). The highwater-levels re-ignited the scientific debate on the impacts of a changing climate on Lake Victoria's water budget. Indeed, the impacts of a changing climate in East Africa (Nicholson, 2017; Ogega et al., 2020; Wainwright et al., 2019) on the biodiversity of the Lake Victoria Basin (LVB) are already being observed at multiple biological levels ranging from genes to biomes. Some of these impacts include enhanced spatio-temporal precipitation variability, a reduction in biodiversity (including fish), periodical lake water-level and quality fluctuations, and dwindling crop yields and emergence of crop diseases in the lake-adjacent farming areas (Tungaraza, 2012; Sayer et al., 2018; Scheffers et al., 2016; van Zwieten et al., 2016). Given that the lake's fishes, and biodiversity in general, are significantly sensitive and vulnerable to climate change (Sayer et al., 2018), adequate monitoring and appropriate conservation action are required to minimize the impacts of climate change on the lake's biodiversity.

Some work has been done towards understanding precipitation patterns and associated water-level fluctuations over Lake Victoria and its basin. For instance, the lake is notorious with intense lightning and convective storms (Albrecht et al., 2016) and its severe weather and water currents have been linked to boat accidents causing approximately 5000 deaths on the lake annually (Barnett, 2013; Cannon et al., 2014). However, the understanding of weather and climate dynamics in the LVB remains limited due to, in part, the inability of current climate models to adequately represent weather and climate dynamics over Lake Victoria (e.g., Finney et al., 2020; Ridder et al., 2021; Vanderkelen et al., 2018b).

With advances in technology, climate models are increasingly becoming more accurate in simulating our atmospheric systems. Indeed, the sixth phase of the Coupled Model Intercomparison Project (CMIP6; Eyring et al., 2016) provides the most advanced structure, so far, coordinating the design and distribution of global climate model simulations. Specifically, CMIP6 simulations seek to broaden the understanding of (1) how the Earth system responds to forcing, (2) what the origins and consequences of systematic model biases are, and (3) and how future climate changes can be assessed given the internal climate variability, predictability, and uncertainties in scenarios (Eyring et al., 2016). CMIP6 provides an ensemble of CMIP-endorsed 
Model Intercomparison Projects (MIPs) that address specific questions and scientific gaps raised from the previous CMIP phases. This article estimates future precipitation changes over the LVB using model simulations from the High-Resolution MIP (HighResMIP; Haarsma et al., 2016) and the Scenario MIP (ScenarioMIP; O’Neill et al., 2016). The rest of the paper is organized into Methodology (2), Results and discussion (3), and Conclusions (4).

\section{Methodology}

\subsection{Study Area}

Located at the intersection of Kenya, Uganda, and Tanzania in Africa's Great Lakes region, Lake Victoria is Africa's largest freshwater body and the world's largest inland fishery supporting at least 40 million inhabitants (UNEP, 2006). The lake and its resources fuel East Africa's economy with the lake's catchment providing about $90 \%$ of hydropower for Uganda, Burundi, and Rwanda. The lake's catchment also provides water to major urban centres including Kampala, Kisumu, and Mwanza. Being the source of the White Nile, one of the two main tributaries of River Nile, the lake's catchment contributes about $70 \%$ of all water reaching Egypt during the dry season over the Ethiopian highlands from which the other main tributary - the Blue Nile system - comes (UNESCO, 1995).

The lake's basin (LVB) is renowned for its richness and endemism in species (Darwall et al., 2005; Seehausen, 2002). It has massive natural resources including forests, fisheries, rangelands, and wetlands from which communities in and around the basin draw their livelihoods. On fisheries alone, total landings from the lake are estimated at over one million tonnes of fish annually (TaabuMunyaho et al., 2016). The lake's fisheries support more than 3 million livelihoods and generate annual revenue exceeding USD 600 million (Njiru et al., 2008; World Bank Group, 2016).

The current study focusses on Lake Victoria and its immediate adjacent catchment area (Figure 1). The lake is located at an altitude of about 1,135 m above sea-level, spanning an area of about $68,000 \mathrm{~km}^{2}$ (Rzóska, 1976). The lake and most of its catchment area receives mean annual precipitation ranging from 1,350 mm over Kenya to about 2,400 mm over Uganda, contributing about $80 \%$ of the lake's water budget (Senay et al., 2014; John V. Sutcliffe, 2009). About 20\% of the lake's water budget comes from 23 rivers from five East African countries namely Kenya, Uganda, Tanzania, Rwanda, and Burundi. The lake's only outflow is the White Nile River - one of the main tributaries of the Nile (Sutcliffe \& Petersen, 2007). 


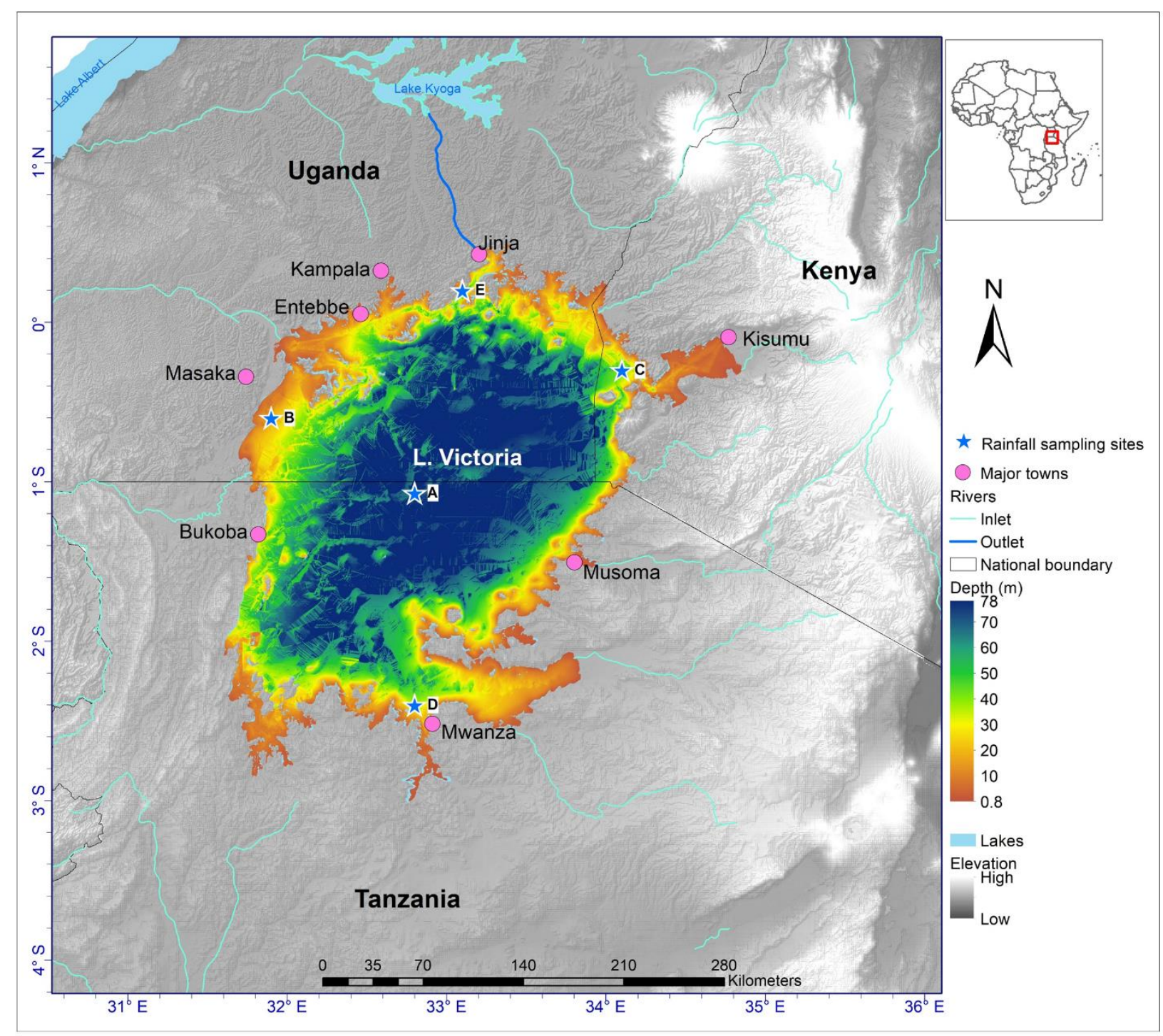

Figure 1. A topographic map of the study domain

The study domain map (Figure 1) is produced using bathymetry data from the Harvard Dataverse (Hamilton et al., 2016), river shapefiles from Food and Agriculture Organization (FAO) geonetwork portal (http://bit.ly/3bkW1Ky), and urban data digitized from google earth and basemap from United States Geological Survey. The points marked with a blue * are used to sample precipitation patterns over specific parts of the lake (parts A, B, C, D and E). The depth of the lake (in meters) is presented in a colour scheme while major urban centres around the lake are represented in the circular purple symbols. 


\subsection{Data}

In this study, the Climate Hazards Group InfraRed Precipitation with Station (CHIRPS) data as the reference precipitation dataset. CHIRPS is a quasi-global precipitation dataset available from 1981 to near present, spanning $50^{\circ} \mathrm{S}-50^{\circ} \mathrm{N}$ and all longitudes. It incorporates climatology, insitu station data, and satellite imagery to form a gridded precipitation time series at $0.05^{\circ}$ horizontal resolution (Funk et al., 2015). The dataset has been validated (e.g., Dinku et al., 2018) and used widely for studies on precipitation in East Africa (e.g., Gebrechorkos et al., 2019; Ogega et al., 2020). In this study, both monthly and daily CHIRPS data are used, for the period 1981-2014 to correspond to the historical period for HighResMIP and ScenarioMIP datasets.

A list of HighResMIP and ScenarioMIP model simulations used in the current study is provided in Table 1. HighResMIP model simulations, made using a multi-model approach to the systematic investigation of the impact of horizontal resolution, address origins and consequences of systematic model biases (Haarsma et al., 2016). Simulations from the ScenarioMIP provide the basis for investigating various science and policy questions particularly relevant to scenario-based analysis such as the role of specific forcings (ScenarioMIP; O’Neill et al., 2016).

Table 1. CMIP6 GCM simulations used in the study. All HighResMIP (ScenarioMIP) simulations are at 50km (100km) nominal resolution. Simulations marked with * provided daily data, those with ** provided both daily and monthly data, and the rest provided monthly data. More information about the models is available at https://esgf-node.llnl.gov/search/cmip6/

\begin{tabular}{|c|c|c|c|}
\hline Category & Model ID & Institution & Experiment \\
\hline \multirow{9}{*}{$\begin{array}{l}\text { HighRes } \\
\text { MIP }\end{array}$} & **CNRM-CM6-1-HR & Centre national de recherches & \multirow{9}{*}{$\begin{array}{ll}- & \text { Hist-1950 } \\
\text { - } & \text { Representative } \\
& \text { Concentration } \\
& \text { Pathway (RCP) } \\
& 8.5\end{array}$} \\
\hline & (r1i1p1f2, r2i1p1f2, & météorologiques (CNRM) and & \\
\hline & and r3i1p1f2) & Centre Européen de Recherche et de & \\
\hline & & Formation Avancée en Calcul & \\
\hline & & Scientifique (CERFACS), France & \\
\hline & **EC-Earth3P-HR & \multirow[t]{2}{*}{ EC-Earth consortium, E.U. } & \\
\hline & $\begin{array}{l}\text { (r1i1p2f1, r2i1p2f1, } \\
\text { and r3i1p2f1) }\end{array}$ & & \\
\hline & $\begin{array}{l}\text { **HadGEM3-GC31- } \\
\text { HH (r1i1p1f1) }\end{array}$ & Met Office Hadley Centre, U.K. & \\
\hline & $\begin{array}{l}\text { **HadGEM3-GC31- } \\
\text { HM (r1i1p1f1) }\end{array}$ & Met Office Hadley Centre, U.K. & \\
\hline \multirow{4}{*}{$\begin{array}{l}\text { Scenario } \\
\text { MIP }\end{array}$} & CESM2 ((r10i1p1f1, & \multirow{3}{*}{$\begin{array}{l}\text { National Center for Atmospheric } \\
\text { Research (NCAR), U.S.A }\end{array}$} & \multirow{4}{*}{$\begin{array}{ll}\text { - } & \text { Historical } \\
\text { - } & \text { Shared } \\
\text { Socioeconomic } \\
\text { Pathway (SSP) } \\
\text { 2-4.5 }\end{array}$} \\
\hline & (r11i1p1f1) & & \\
\hline & $\begin{array}{l}\text { CESM2-WACCM } \\
\text { (r3i1p1f1) }\end{array}$ & & \\
\hline & CIESM (r1i1p1f1) & $\begin{array}{l}\text { The Mediterranean Science } \\
\text { Commission, Monaco }\end{array}$ & \\
\hline
\end{tabular}




\begin{tabular}{|c|c|c|}
\hline $\begin{array}{l}\text { BCC-CSM2-MR } \\
\text { (r1i1p1f1) }\end{array}$ & The Beijing Climate Center, China & - $\quad$ SSP5-8.5 \\
\hline $\begin{array}{l}\text { CAMS-CSM1-0 } \\
\text { (r1i1p1f1, r2i1p1f1) }\end{array}$ & $\begin{array}{l}\text { The Chinese Academy of } \\
\text { Meteorological Sciences, China }\end{array}$ & \\
\hline $\begin{array}{l}\text { CAS-ESM2-0 } \\
\text { (r1i1p1f1, r3i1p1f1) }\end{array}$ & The Chinese Academy of Sciences & \\
\hline $\begin{array}{l}\text { FGOALS-f3-L } \\
\text { (r1i1p1f1) }\end{array}$ & The Chinese Academy of Sciences & \\
\hline $\begin{array}{l}\text { FIO-ESM-2-0 } \\
\text { (r2i1p1f1) }\end{array}$ & $\begin{array}{l}\text { First Institute of Oceanography } \\
\text { (FIO), Ministry of Natural Resources } \\
\text { and Qingdao National Laboratory for } \\
\text { Marine Science and Technology, } \\
\text { China }\end{array}$ & \\
\hline $\begin{array}{l}\text { INM-CM4-8 } \\
\text { (r1i1p1f1) }\end{array}$ & $\begin{array}{l}\text { The Institute for Numerical } \\
\text { Mathematics, Russian Academy of } \\
\text { Science, Russia }\end{array}$ & \\
\hline TaiESM1 (r1i1p1f1) & $\begin{array}{l}\text { The Research Center for } \\
\text { Environmental Changes, Academia } \\
\text { Sinica, Taiwan }\end{array}$ & \\
\hline $\begin{array}{l}\text { *CMCC-CM2-SR5 } \\
\text { (r1i1p1f1) }\end{array}$ & $\begin{array}{l}\text { The Fondazione Centro Euro- } \\
\text { Mediterraneo sui Cambiamenti }\end{array}$ & \\
\hline $\begin{array}{l}\text { *CMCC-ESM2 } \\
\text { (r1i1p1f1) }\end{array}$ & Climatici, Italy & \\
\hline $\begin{array}{l}\text { *GFDL-CM4 } \\
\text { (r1i1p1f1) }\end{array}$ & \multirow{2}{*}{$\begin{array}{l}\text { The National Oceanic and } \\
\text { Atmospheric Administration, } \\
\text { Geophysical Fluid Dynamics } \\
\text { Laboratory, USA }\end{array}$} & \\
\hline $\begin{array}{l}\text { *GFDL-ESM4 } \\
\text { (r1i1p1f1) }\end{array}$ & & \\
\hline $\begin{array}{l}\text { *MPI-ESM1-2-HR } \\
\text { (r1i1p1f1, r2i1p1f1) }\end{array}$ & $\begin{array}{l}\text { The Max Planck Institute for } \\
\text { Meteorology, Germany }\end{array}$ & \\
\hline $\begin{array}{l}* \text { MRI-ESM2-0 } \\
\text { (r1i1p1f1) }\end{array}$ & $\begin{array}{l}\text { The Meteorological Research } \\
\text { Institute, Japan }\end{array}$ & \\
\hline
\end{tabular}

Computations were done for each model simulation in native data resolutions and grids (as in Diaconescu et al., 2015) before bilinearly interpolating (Zhou et al., 2017) the final files onto the CHIRPS regular grid to enable comparison between various model simulations and observations and multi-model averaging.

\subsection{Methods}

First, a performance assessment of ScenarioMIP and HighResMIP GCM simulations in reproducing precipitation patterns over the study domain is done relative to observations. The performance assessment is done by calculating the differences in mean annual (ANN) and seasonal (MAM, JJA, OND) climatology between GCM simulations and observations, using monthly data 
and the period 1981-2014; corresponding to data availability for both model simulations (historical experiment) and observations. The student $t$ test is used to calculate significant values at the 99\% confidence interval. To appreciate the performance of model simulations in reproducing interannual precipitation patterns over the study area, mean absolute errors (MAE; Equation 1), relative to observations are computed for each model simulation. Compared to other measures of dispersion, MAEs give better mean error magnitudes (Chai \& Draxler, 2014; Willmott \& Matsuura, 2005). The MAEs are computed using detrended data to minimize the potential influence of the non-stationarity of data (Wu et al., 2007).

$$
M A E=\frac{1}{n} \sum_{i=1}^{n}\left|y_{i}-x_{i}\right| \quad \text { Equation } 1
$$

where $n$ represents the number of observations while $x_{i}$ and $y_{i}$ represent observational and simulated values, respectively. The smaller the MAE, the better the simulation.

Secondly, an assessment of future precipitation patterns over the LVB id done by calculating differences in mean values between the future period relative to the control period (1971-1999). The changes are calculated for annual precipitation indices and statistics presented in Table 2. Here, the period 2020-2049 is selected to represent the "near future" while 2070-2099 represents the "future". The student $t$ test is used to calculate significant values at the $99 \%$ confidence interval.

Table 2. A list of annual precipitation indices and annual precipitation cycle statistics used in the current study. All units are in $\mathrm{mm}$

\begin{tabular}{|c|c|c|}
\hline Descriptor & Acronym & Description \\
\hline $\begin{array}{l}\text { Simple } \\
\text { precipitation } \\
\text { intensity index }\end{array}$ & SDII & $\begin{array}{l}\text { Mean precipitation amount on a wet day. Let } \mathrm{RR}_{i j} \text { be the daily } \\
\text { precipitation amount on wet day } \mathrm{w}(\mathrm{RR} \geq 1 \mathrm{~mm}) \text { in period } j \text {. If } \\
W \text { represents the number of wet days in } j \text { then the simple } \\
\text { precipitation intensity index } \mathrm{SDII}_{j}=\operatorname{sum}\left(\mathrm{RR}_{w j}\right) / \mathrm{W}\end{array}$ \\
\hline $\begin{array}{l}\text { Max 5-day } \\
\text { precipitation } \\
\text { amount }\end{array}$ & Rx5day & Maximum consecutive 5-day precipitation \\
\hline $\begin{array}{l}\text { Width of the } \\
\text { right tail } \\
\text { distribution of } \\
\text { precipitation }\end{array}$ & 99p-90p & $\begin{array}{l}\text { Calculated as the difference between the } 99^{\text {th }} \text { and the } 90^{\text {th }} \\
\text { percentiles }(99 \mathrm{p}-90 \mathrm{p}) \text {, where } 90 \mathrm{p} \text { defined as follows; } \\
\text { for every adjacent sequence } t \_1, \ldots, t \_n \text { of timesteps of the } \\
\text { same year, } 90 \text { p is given by } \\
\qquad(t, x)=p^{\text {th }} \text { percentile }\left\{i\left(t^{\prime}, x\right), t_{1}<t^{\prime} \leq t_{n}\right\} \text {; } \\
\text { here computed for the } 90^{\text {th }} \text { percentile. For this study, } \\
\text { 90p represents the threshold for identifying heavy } \\
\text { precipitation events. }\end{array}$ \\
\hline
\end{tabular}




\begin{tabular}{|c|c|c|}
\hline & & $\begin{array}{l}\text { 99p represents very intense precipitation events and is defined } \\
\text { as; } \\
\text { for every adjacent sequence } t_{-} 1, \ldots, t \_n \text { of timesteps of the } \\
\text { same year, 99p is given by } \\
\qquad o(t, x)=p^{\text {th }} \text { percentile }\left\{i\left(t^{\prime}, x\right), t_{1}<t^{\prime} \leq t_{n}\right\} \text {; } \\
\quad \text { here computed for the } 99^{\text {th }} \text { percentile. }\end{array}$ \\
\hline $\begin{array}{l}\text { Mean annual } \\
\text { precipitation }\end{array}$ & ANN & $\begin{array}{l}\text { For every adjacent sequence } t \_1, \ldots, t \_n \text { of timesteps of the } \\
\text { same year it is: } \\
o(t, x)=\text { mean }\left\{i\left(t^{\prime}, x\right), t_{1}<t^{\prime} \leq t_{n}\right\} \text {; } \\
\text { computed for January-December of every year in the series }\end{array}$ \\
\hline $\begin{array}{l}\text { Mean } \\
\text { precipitation for } \\
\text { March to May } \\
\text { season }\end{array}$ & MAM & $\begin{array}{l}\text { For every adjacent sequence } t \_1, \ldots, t \_n \text { of timesteps of the } \\
\text { same year it is: } \\
o(t, x)=\text { mean }\left\{i\left(t^{\prime}, x\right), t_{1}<t^{\prime} \leq t_{n}\right\} \text {; } \\
\text { computed for MAM of every year in the series }\end{array}$ \\
\hline $\begin{array}{l}\text { Mean } \\
\text { precipitation for } \\
\text { June to August } \\
\text { season }\end{array}$ & JJA & $\begin{array}{l}\text { For every adjacent sequence } t \_1, \ldots, t \_n \text { of timesteps of the } \\
\text { same year it is: } \\
o(t, x)=\text { mean }\left\{i\left(t^{\prime}, x\right), t_{1}<t^{\prime} \leq t_{n}\right\} \text {; } \\
\text { computed for JJA of every year in the series }\end{array}$ \\
\hline $\begin{array}{l}\text { Mean } \\
\text { precipitation for } \\
\text { October to } \\
\text { December } \\
\text { season }\end{array}$ & OND & $\begin{array}{l}\text { For every adjacent sequence } t_{-} 1, \ldots, t \_n \text { of timesteps of the } \\
\text { same year it is: } \\
o(t, x)=\text { mean }\left\{i\left(t^{\prime}, x\right), t_{1}<t^{\prime} \leq t_{n}\right\} \text {; } \\
\text { computed for OND of every year in the series }\end{array}$ \\
\hline
\end{tabular}

To estimate heavy precipitation events in the LVB, the 99p-90p statistic is used to represent the right tail of precipitation distribution (as in Scoccimarro et al., 2016). Here, 90p and 99p are calculated by accumulating daily precipitation values over each grid point with 99p and 90p representing very intense and heavy precipitation events, respectively. The percentiles for 99p and 90p (as detailed in Table 2) are calculated for all days in the data.

\section{Results and discussion}

\subsection{Validation of CMIP6 historical simulations over LVB}

A plot of precipitation climatology over the study domain (Figure 2, top panel) shows MAM to be the wettest season, followed by OND. Here, more precipitation is recorded on Lake Victoria than the onshore areas, with the western part of the lake showing a wetter regime than the rest of the lake. A similar pattern is recorded for the OND season, except with lower precipitation values than those of the MAM season. The JJA season is relatively dry with most of the domain recording less than $50 \mathrm{~mm} / \mathrm{month}$ of precipitation. Here, the southern part of the domain is drier than the northern part, with precipitation values over parts of western Kenya (north-east of the study domain) 
exceeding $150 \mathrm{~mm} / \mathrm{month}$. Annually (ANN), most of the study domain records at least 100 $\mathrm{mm} / \mathrm{month}$ with areas over the lake and western Kenya recording the highest values. The highest mean precipitation values (up to $300 \mathrm{~mm} / \mathrm{month}$ ) are recorded in the MAM season while the least values (less than $50 \mathrm{~mm} /$ month) are recorded in JJA.

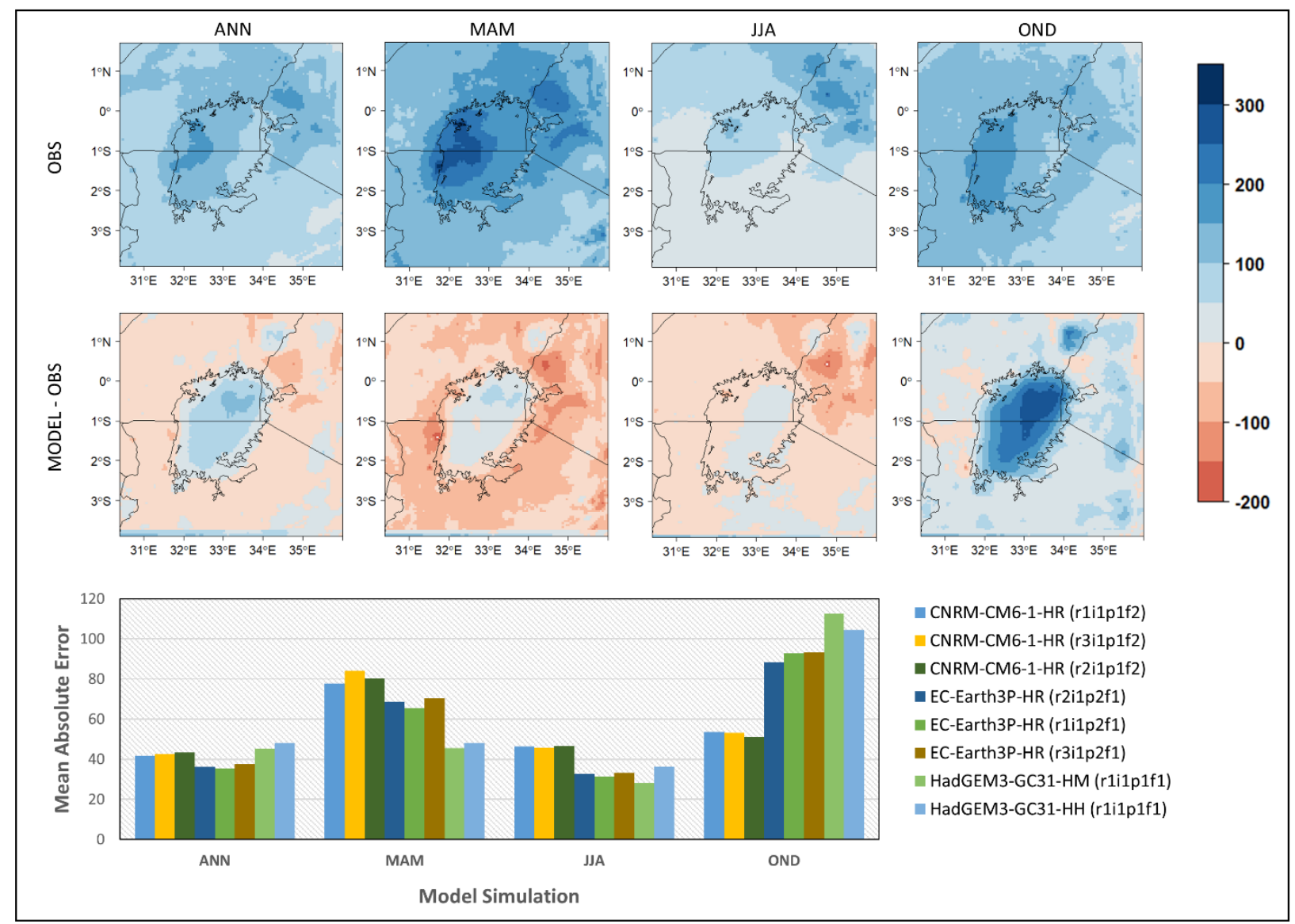

Figure 2. Precipitation climatology (OBS, top panel) and differences in mean precipitation between an ensemble mean of HighResMIP model simulations and observations (MODEL - OBS, middle panel), averaged for annual (ANN) and seasonal (MAM, JJA, and OND) precipitation, for the period 1981-2014. The mean absolute errors (relative to observations) for individual HighResMIP model simulations are presented as histograms (bottom panel). Nearly all values on the spatial plots are significant at $99 \%$ confidence interval and all units are in $\mathrm{mm} / \mathrm{month}$

Significant differences in mean precipitation between HighResMIP model simulations and observations (Figure 2, middle panel) are shown, especially at the immediate lake-adjacent areas. Generally, HighResMIP simulations tend to under-estimate (over-estimate) precipitation over the lake-adjacent (the lake) areas for ANN, MAM, and JJA. Here, OND is the most over-estimated season with biases of up-to $300 \mathrm{~mm} /$ month recorded over parts of Lake Victoria. 
Considering mean absolute errors for individual model simulations (Figure 2, bottom panel), ANN is best reproduced by EC-Earth3P-HR simulations (r1i1p2f1, r2i1p2f1, and r3i1p2f1, respectively). MAM is best reproduced by HadGEM3-GC31-HM(r1i1p1f1), HadGEM3-GC31HH(r1i1p1f1), and EC-Earth3P-HR(r1i1p2f1), respectively while JJA is best reproduced by HadGEM3-GC31-HM(r1i1p1f1), EC-Earth3P-HR(r1i1p2f1), and EC-Earth3P-HR(r2i1p2f1). CNRM-CM6-1-HR(r2i1p1f2), CNRM-CM6-1-HR(r3i1p1f2), and CNRM-CM6-1-HR(r1i1p1f2) give the best simulation for the OND season. Generally, ANN, MAM, and JJA are best reproduced by simulations from the EC-Earth3P-HR model while the OND season is best reproduced by the CNRM-CM6-1-HR simulations.

Simulations from the ScenarioMIP models (Figure 3, middle panel) show a relatively better performance than those from HighResMIP, especially for the OND season. Here, the simulations show a generally wet (dry) bias for ANN and OND (MAM and JJA). A general under-estimation of precipitation values over the lake is shown compared to the lake-adjacent areas of the study domain. Nevertheless, the ScenarioMIP model simulations show minimal biases ranging between -150 and $100 \mathrm{~mm} / \mathrm{month}$ over most of the study domain.

Considering the MAEs for individual model simulations (Figure 3, bottom panel), ANN is best reproduced by CAMS-CSM1-0(r2i1p1f1), CAS-ESM2-0(r3i1p1f1), and CAS-ESM2-0(r1i1p1f1), respectively. The BCC-CSM2-MR(r1i1p1f1), CESM2(r11i1p1f1), and CESM2(r10i1p1f1) give the best simulation for MAM while JJA is best reproduced by INM-CM4-8(r1i1p1f1), BCCCSM2-MR(r1i1p1f1), and CAS-ESM2-0(r1i1p1f1), respectively. CAMS-CSM1-0(r1i1p1f1), CAMS-CSM1-0(r2i1p1f1), and CAS-ESM2-0(r3i1p1f1), respectively, give the best reproduction of the OND season. Based on the top three simulations per category, the CAMS-CSM1-0, CASESM2-0, and BCC-CSM2-MR emerge as the top performers compared to the other ScenarioMIP model simulations considered in the current study. 


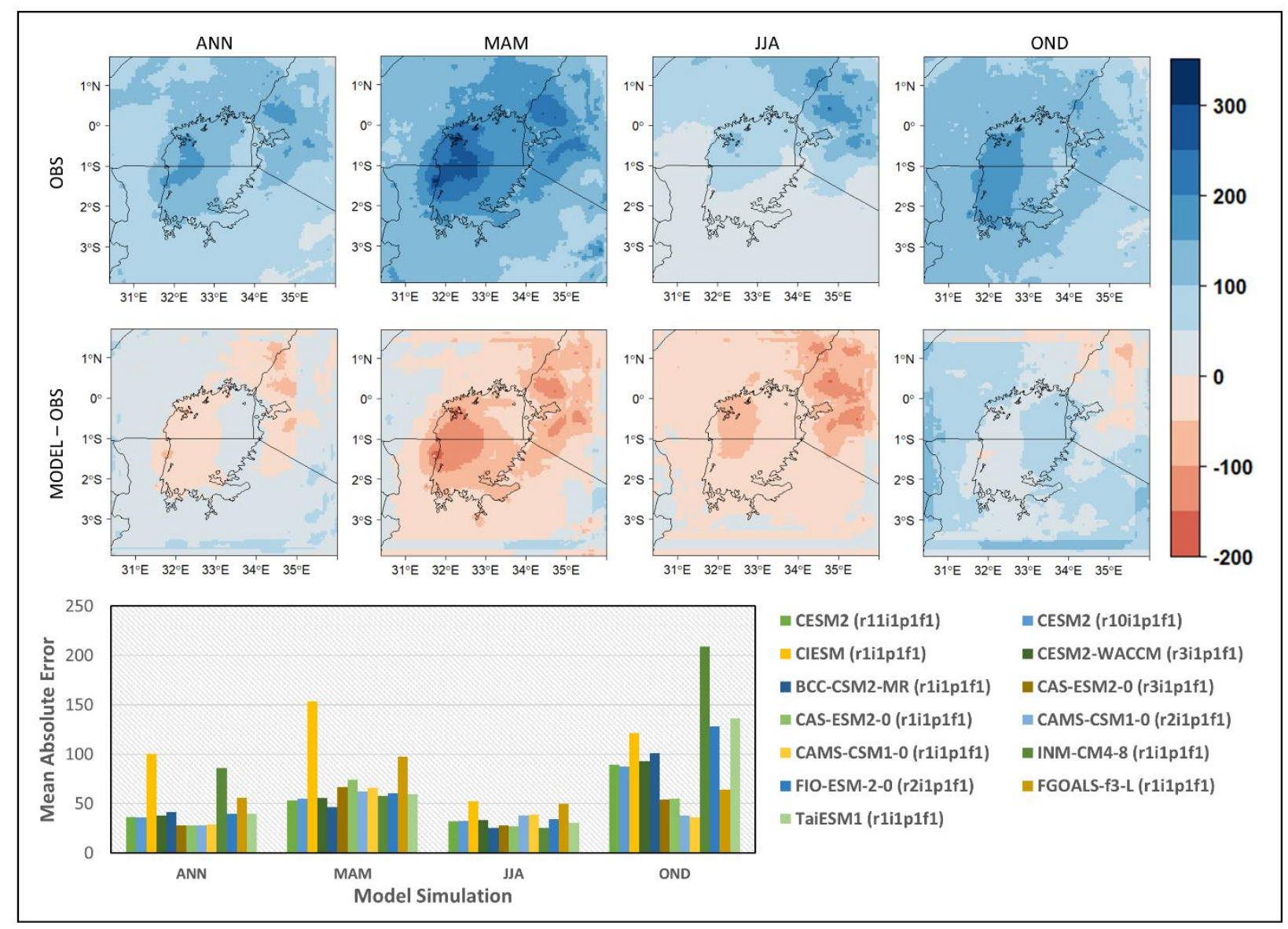

Figure 3. As in Figure 2 but for ScenarioMIP simulations

As noted by other CMIP6 model simulation evaluation studies (e.g., Akinsanola et al., 2021; Ngoma et al., 2021), CMIP6 model simulations generally show biases in representing regional precipitation patterns. For the current study domain, biases shown could be resulting from, among other factors, local climate and mesoscale convective systems (Ridder et al., 2021) and the general complexity of East Africa's large-scale controlled climate (Li et al., 2016; Nicholson, 2017). However, preliminary studies (e.g., Ayugi et al., 2021) have shown an improved performance by CMIP6 models than those from CMIP5 models in reproducing East Africa's precipitation patterns.

Given the relatively small number of available CMIP6 datasets, all the HighResMIP and ScenarioMIP GCM simulations assessed in this paper are used in the analysis of future precipitation patterns in the LVB. 


\subsection{Analysis of future precipitation patterns over Lake Victoria}

3.2.1 Projections for the near-future period (2020-2049)

An analysis of near-future precipitation changes in the LVB using HighResMIP simulations (Figure 4) shows an increase in mean ANN, MAM, JJA, and OND precipitation relative to the present. Spatially, most of the domain records significant changes in precipitation with marginally more precipitation recorded over the lake than over the rest of the study domain. The MAM season shows the least significant changes in precipitation compared to JJA, OND, and ANN. Averaging the precipitation changes over the study domain, the OND season shows the highest (17\%) increase in precipitation followed by JJA (15\%) and MAM (4\%), respectively. The mean precipitation change per year (ANN) for the LVB is about 16\% relative to the control period (1970-1999). 


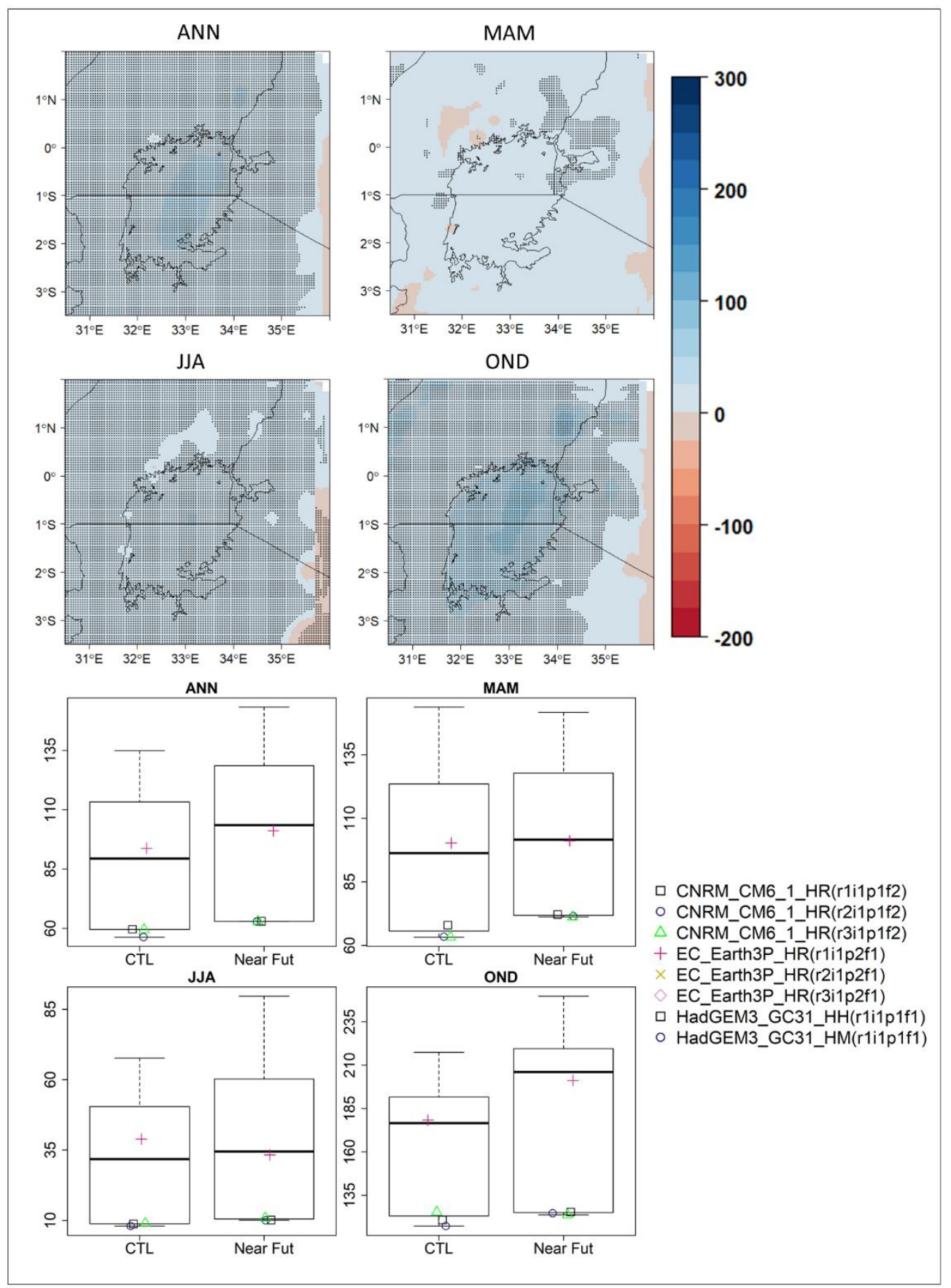

Figure 4. Differences in mean annual (ANN) and seasonal (MAM, JJA, and OND) precipitation over the LVB for the period 2020-2049 relative to the 1970-1999 control (CTL), using monthly HighResMIP projections under RCP 8.5. The spatial plots are made from an ensemble mean of all the model simulations listed. All units are in $\mathrm{mm} / \mathrm{month}$ while stippling on the spatial plots shows significant changes at $99 \%$ confidence interval.

Using ScenarioMIP model simulations (Figure 5), generally wetter precipitation conditions are recorded for both SSP2-4.5 and SSP5-8.5 scenarios, relative to the control period. The least changes are recorded in the JJA season while OND records the greatest precipitation change, for both scenarios. More precipitation changes are projected for the study domain under SSP5-8.5 than 
under SSP2-4.5, with all seasons showing significant values over most of the study domain. When averaged over the entire study domain, the MAM season records an increase in precipitation of about 8\% and 5\% under SSP2-4.5 and SSP5-8.5, respectively. The JJA season records the highest increase (relative to the control period) of approximately $10 \%$ and $26 \%$ under the SSP2-4.5 and SSP5-8.5 scenarios, respectively. A modest increase in OND precipitation is recorded under the SSP2-4.5 (3\%) and SSP5-8.5 (7\%) scenarios. Annually, an average precipitation increase of about $7 \%$ and $10 \%$ is recorded for the LVB under the SSP2-4.5 and SSP5-8.5 scenarios, respectively.

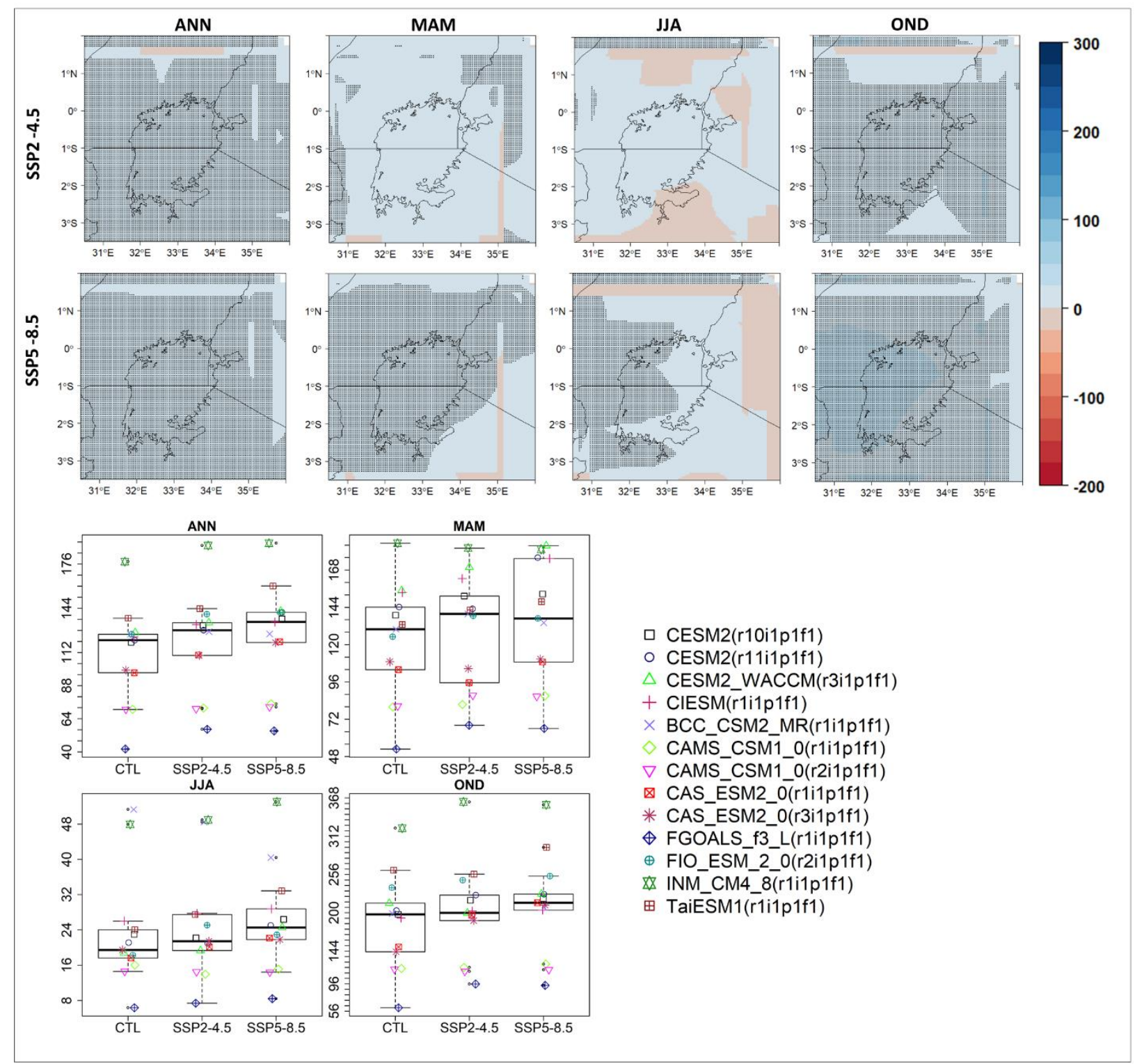

Figure 5. Differences in mean annual (ANN) and seasonal (MAM, JJA, and OND) precipitation over the LVB for the period 2020-2049 relative to the 1970-1999 control (CTL), using monthly ScenarioMIP projections under SSP2-4.5 and SSP5-8.5. The spatial plots are made from an ensemble mean of all the model simulations listed. All units are in $\mathrm{mm} / \mathrm{month}$ while stippling on the spatial plots shows significant changes at 99\% confidence interval 
An analysis of the daily precipitation statistics (Figure 6) shows generally wetter conditions in the period 2020-2049 relative to the 1970-1999 baseline. Here, greater values are generally recorded over the lake compared to the rest of the study area. Specifically, the width of the right tail distribution of precipitation (99p-90p) increases by about $5 \mathrm{~mm} /$ day over most of the study domain, corresponding to an average increase of about $14 \%$ for the study area. Wetter conditions (about 15\%) are recorded for the RX5Day with values exceeding $10 \mathrm{~mm} /$ day over the lake. The SDII records an average increase of about $9 \%$ with values exceeding $2 \mathrm{~mm}$ /day recorded over the lake.
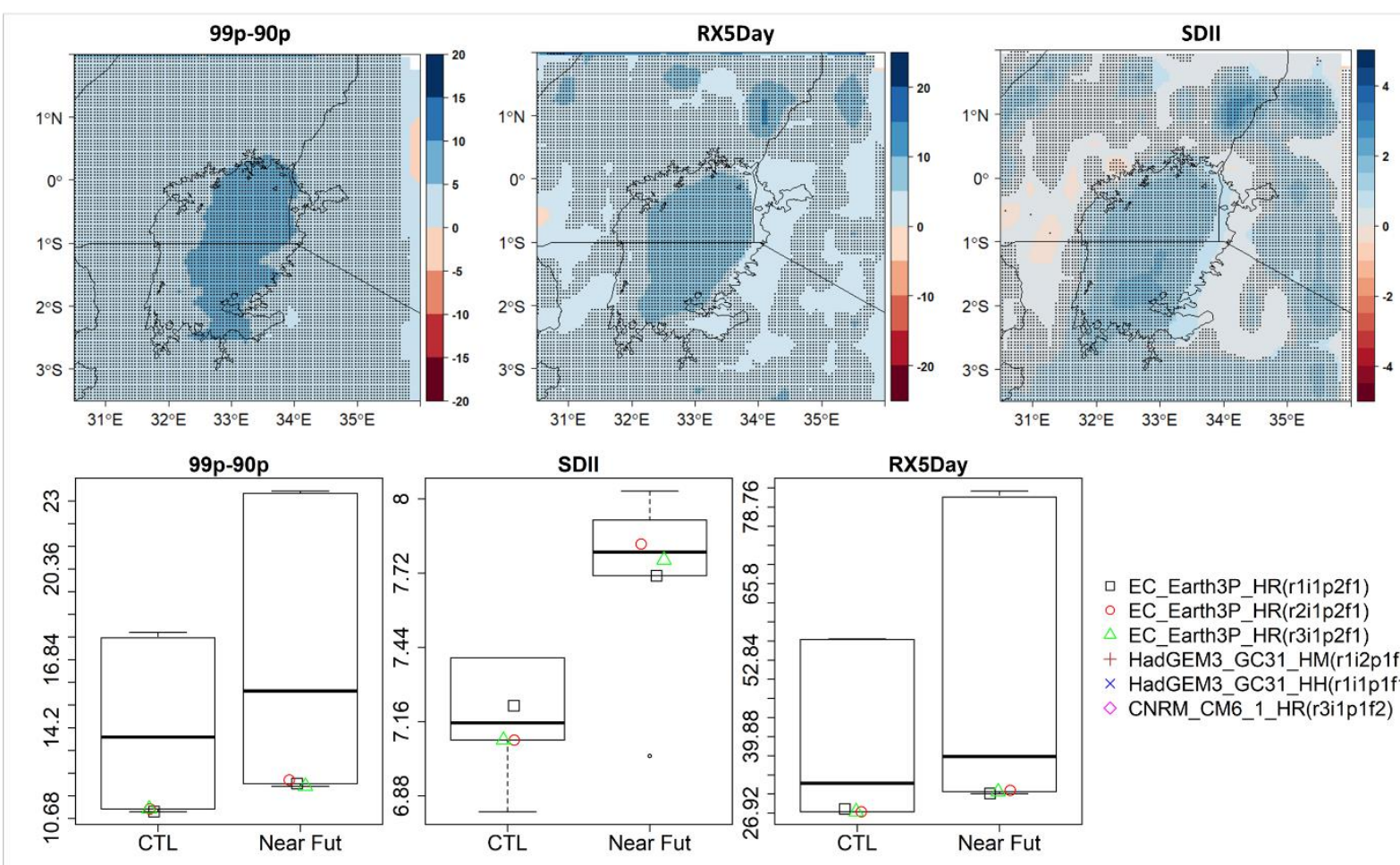

口 EC_Earth3P_HR(r1i1p2f1)

- EC_Earth3P_HR(r2i1p2f1)

$\triangle$ EC_Earth3P_HR(r3i1p2f1)

+ HadGEM3_GC31_HM(r1i2p1f1)

$\times$ HadGEM3_GC31_HH(r1i1p1f1)

$\diamond$ CNRM_CM6_1_HR(r3i1p1f2)

Figure 6. Differences in mean 99p-90p, SDII, and RX5Day values for the period 2020-2049 relative to the 1970-1999 control (CTL), using HighResMIP projections under RCP 8.5. The spatial plots are made from an ensemble mean of all the model simulations listed. All units are in $\mathrm{mm} /$ day while stippling on the spatial plots shows significant changes at $99 \%$ confidence interval

Projections from the ScenarioMIP model simulations (Figure 7) generally agree with those from the HighResMIP model simulations (Figure 6) in terms of the signal and magnitude of precipitation change in the near-future period relative to the control period. Here, both ScenarioMIP and HighResMIP model simulations generally agree on the magnitude of the change for 99p-90p and RX5Day. However, the ScenarioMIP model simulations show a smaller change in SDII (4\%) than HighResMIP model simulations (9\%). No discernible differences are shown between values under SSP2-4.5 and SSP5-8.5 scenarios. 


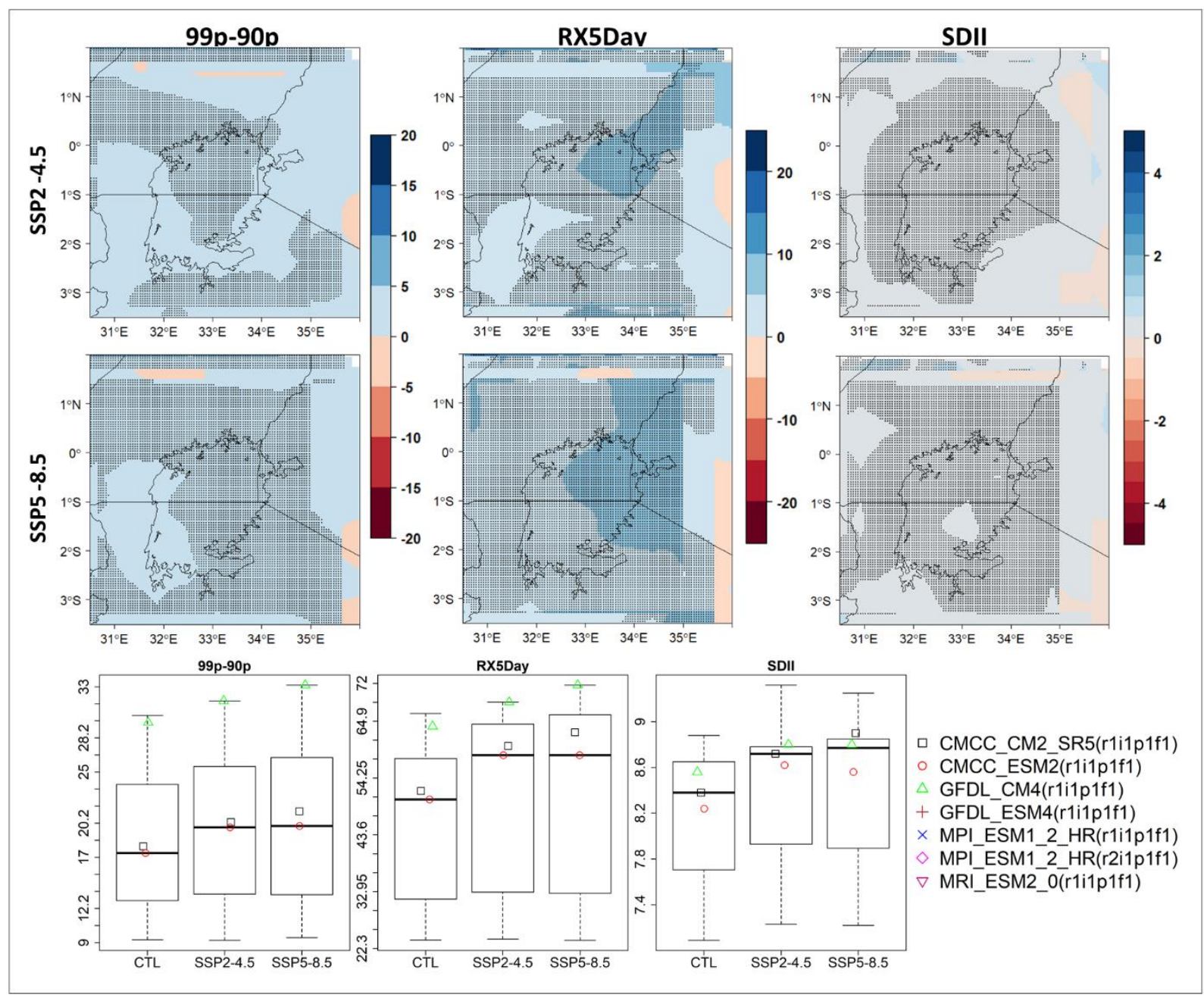

Figure 7. Differences in mean 99p-90p, SDII, and RX5Day values for the period 2020-2049 relative to the 1970-1999 control (CTL), using ScenarioMIP projections under SSP2-4.5 and SSP5-8.5 scenarios. The spatial plots are made from an ensemble mean of all the model simulations listed. All units are in $\mathrm{mm} /$ day while stippling on the spatial plots shows significant changes at 99\% confidence interval

Results from this study show a potential for increased heavy precipitation events in the LVB region by the year 2049. Notably, significant annual mean precipitation values are recorded for nearly all the study domain - alluding to a possibility of prolonged rainy seasons for the LVB. Given that direct precipitation accounts for about $80 \%$ of Lake Victoria's water budget (Sutcliffe \& Petersen, 2007), the apparent increase in precipitation over Lake Victoria, and its catchment area, may lead to more rampant lake water-level fluctuations. While the changes shown are modest, they can potentially affect communities and ecosystems that rely on the water resources of Lake Victoria. Hence, more investment in early warning and disaster risk reduction measures is required to minimize the potential impact of lake water-level fluctuations on communities in the LVB. 


\subsubsection{Projections for the future period (2070-2099)}

Compared to the 2020-2049 period, projections show more changes in precipitation for the period 2070-2099 under both SSP2-4.5 and SSP5-8.5 (Figure 8). The projections show generally significant wetter conditions over most of the study domain for all the seasons, relative to the 19701999 baseline. Here, the JJA season shows the greatest increase (39\% and 71\% under SSP2-4.5 and SSP5-8.5, respectively) compared to the other seasons. The MAM season records an increase precipitation of $14 \%$ and $29 \%$ while precipitation in the OND season increases by $22 \%$ and $10 \%$ under SSP2-4.5 and SSP5-8.5, respectively. Annually, the projections show an increase in precipitation by $18 \%$ and $31 \%$ by the end of the $21^{\text {st }}$ century, under SSP2- 4.5 and SSP -8.5 , respectively. 


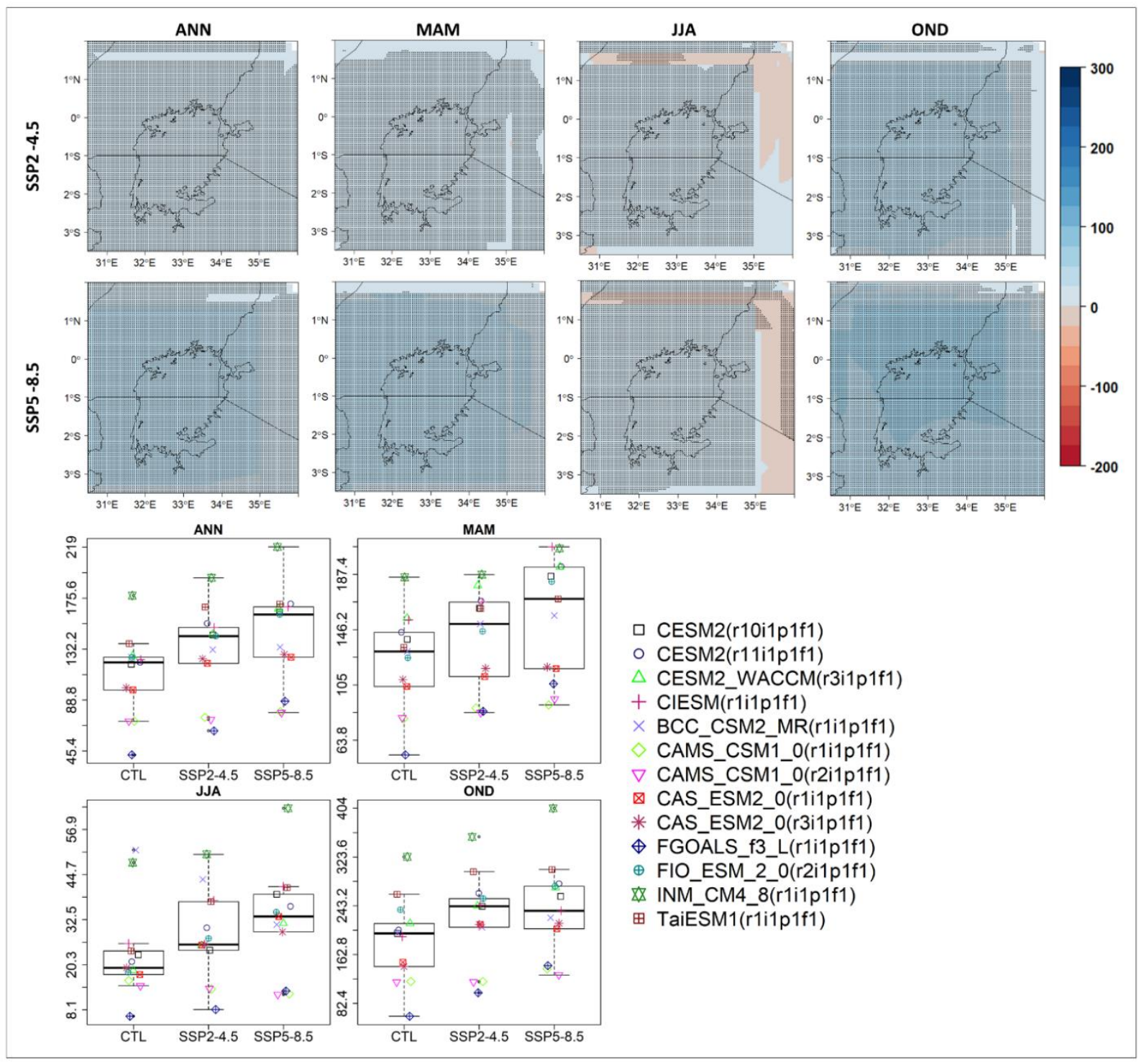

Figure 8. Differences in mean annual (ANN) and seasonal (MAM, JJA, and OND) precipitation over the LVB for the period 2070-2099 relative to the 1970-1999 control (CTL), using monthly ScenarioMIP projections under SSP2-4.5 and SSP5-8.5. The spatial plots are made from an ensemble mean of all the model simulations listed. All units are in $\mathrm{mm} / \mathrm{month}$ while stippling on the spatial plots shows significant changes at 99\% confidence interval

Projections show a general increase in 99p-90p, RX5Day, and SDII values for the study domain under both SSP2-4.5 and SSP5-8.5 scenarios. Here, the greatest changes are seen over Lake Victoria and immediate lake-adjacent areas. The 99p-90p statistic values increase by up-to 10 $\mathrm{mm}$ /day over most of the domain under SSP2-4.5. The values exceed $15 \mathrm{~mm} /$ day under SSP5-8.5, especially over Lake Victoria. The RX5Day index increases by up-to $15 \mathrm{~mm} /$ day under SSP2-4.5, especially over the lake. Values exceeding $20 \mathrm{~mm} /$ day are recorded for the RX5Day index under SSP5-8.5. The SDII index increases by about $1 \mathrm{~mm} /$ day and $1.5 \mathrm{~mm}$ /day under SSP2-4.5 and SSP5-8.5, respectively. On average, the 99p-90p is projected to increase by $50 \%$ and $94 \%$ under 
SSP2-4.5 and SSP5-8.5, respectively. An increase of 49\% and 71\% in RX5Day values is expected for the study domain while SDII values are expected to increase by $12 \%$ and 14\% under SSP2-4.5 and SSP5-8.5, respectively. These statistics point to a high possibility of more frequent, intense, and heavy precipitation events over the study domain by year 2100 .

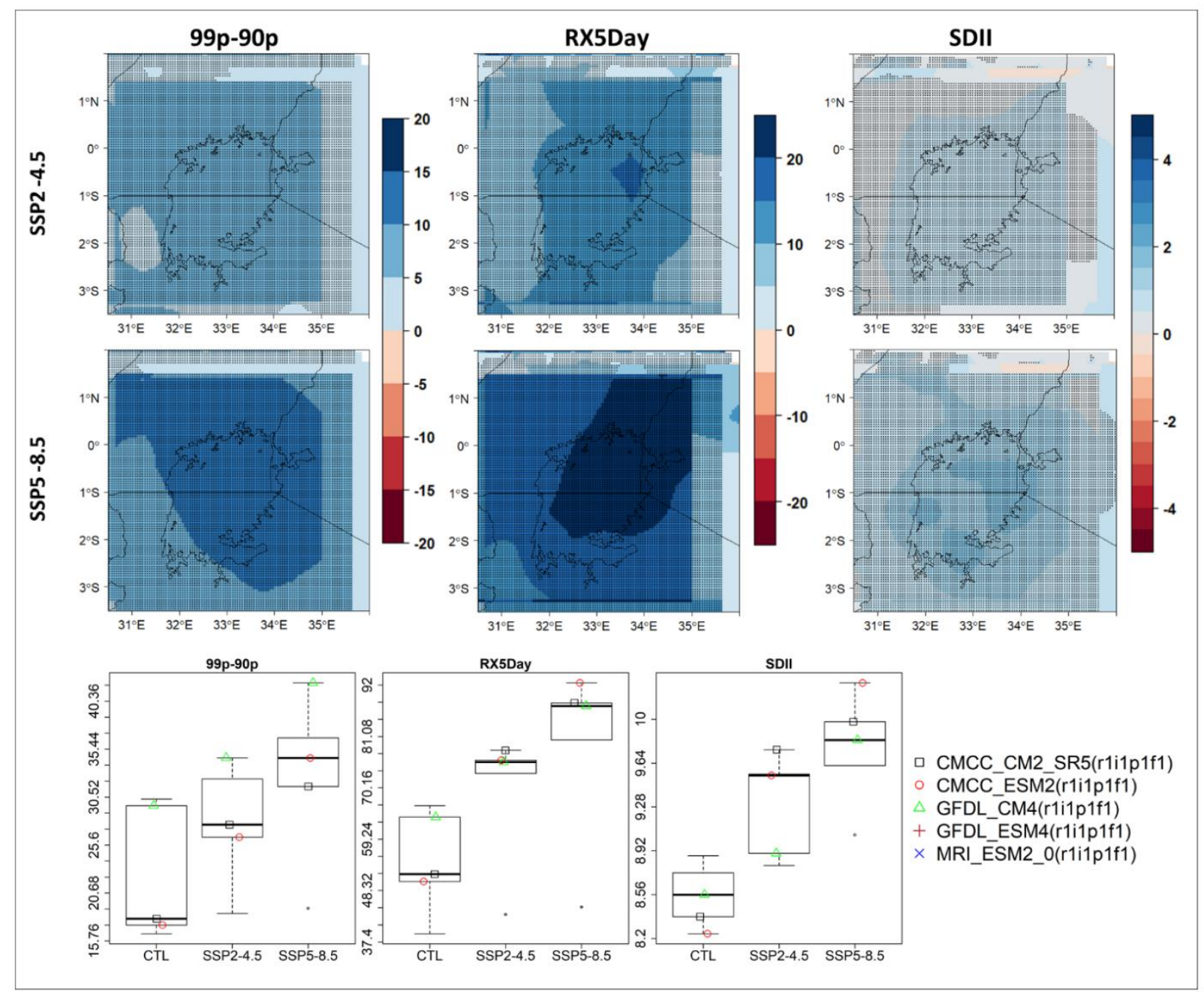

Figure 9. Differences in mean 99p-90p, RX5Day, and SDII values over the LVB for the period 2070-2099 relative to the 19701999 control (CTL), using ScenarioMIP projections under SSP2-4.5 and SSP5-8.5. The spatial plots are made from an ensemble mean of all the model simulations listed. All units are in $\mathrm{mm} /$ day while stippling on the spatial plots shows significant changes at 99\% confidence interval

Given the high sensitivity of the Lake Victoria Catchment area to weather and climate change and variability (Cannon et al., 2014; Sayer et al., 2018; van Zwieten et al., 2016), the current study provides useful scientific evidence to inform disaster risk reduction and climate change adaptation strategies for the LVB. Specifically, the projected increase in the width of the right tail precipitation distribution (99p-90p) in the LVB call for more adequate measures to minimize the associated potential hazards. Currently, about 5,000 people perish annually on the lake, most of 
whom are fishermen (Cannon et al., 2014). The projected increase in precipitation intensity, coupled with an intensification of hazardous thunderstorms over Lake Victoria (Thiery et al., 2016), call for adaptive capacity strengthening for fishermen and lake-adjacent communities most of whom are vulnerable to disaster risk associated with extreme weather and climate events (Cinner et al., 2015). Additionally, the rapidly increasing population density and growth rate (World Bank, 2018) is likely to decrease the LVB's forest cover (Stehfest et al., 2019) and, hence, its capacity to hold flood waters - resulting in a high runoff coefficient (Kundzewicz et al., 2014). The net effect of increased precipitation and a high runoff coefficient is a high likelihood of enhanced waterlevel fluctuations in Lake Victoria.

Further, understanding future precipitation variability over the LVB can potentially contribute to enhanced planning and management of water resources for the greater Nile basin. Currently, the Nile basin is experiencing a diplomatic tiff between Ethiopia, on one hand, and Sudan and Egypt, on the other, resulting from the construction of the Grand Ethiopian Renaissance Dam (GERD) on the Blue Nile (Roussi, 2019; Stokstad, 2016). With GERD, the waters of the White Nile originating in Lake Victoria - become an important alternative in supporting socio-economic activities for Nile-dependent communities downstream.

\section{Conclusions}

This article analyses future precipitation changes over the LVB using HighResMIP and ScenarioMIP simulations from CMIP6. From the analysis, enhanced precipitation changes over Lake Victoria are shown compared to the changes in the rest of the study domain. Generally, mean annual precipitation over the study domain is shown to increase by about 7\% (by year 2049) and 18\% (by year 2100), under the SSP2-4.5 scenario. Under the SSP5-8.5 scenario, mean ANN precipitation is expected to increase by $10 \%$ and 31\% by year 2049 and year 2100, respectively, relative to the 1970-1999 control period. The JJA season shows the greatest increase in precipitation (relative to the control period) with 39\% and 71\% under SSP2-4.5 and SSP5-8.5 scenarios, respectively, by year 2100 .

Additionally, a 12\% and 14\% increase in mean SDII values over the study domain is expected by year 2100, under SSP2-4.5 and SSP5-8.5, respectively. The maximum 5-day precipitation values (RX5Day) are expected to increase by $49 \%$ and $71 \%$ by the end of the current century under SSP2- 
4.5 and SSP5-8.5, respectively. Further, the width of the right tail distribution of precipitation (99p-90p) extends by 50\% and 94\% under the under SSP2-4.5 and SSP5-8.5, respectively. Given that direct precipitation accounts for about $80 \%$ of Lake Victoria's water budget, the lake's future water-level fluctuations are likely to be more rampant and unpredictable under the changing climate. The extreme precipitation events could potentially disrupt normal ecosystem and socioeconomic functioning of the LVB. Hence, enhanced production and use of climate services is recommended to minimize the risk posed by potentially high water-level fluctuations in Lake Victoria and, ultimately, enhance the socio-economic safety of communities in the LVB. Results from the current study provide a basis for further research to enhance the understanding of climate change and variability over the LVB to minimize the risks posed by extreme events and, hence, inform sustainability in the use of Lake Victoria's water resources.

\section{Acknowledgment}

The authors appreciate the contribution of various organizations whose climate datasets made the current study possible. The anonymous reviewers whose comments helped shape this article are highly appreciated. Errors, if any, are those of the authors and not the institutions to which they are affiliated. 
References

Akinsanola, A. A., Ongoma, V., \& Kooperman, G. J. (2021). Evaluation of CMIP6 models in simulating the statistics of extreme precipitation over Eastern Africa. Atmospheric Research, 254, 105509. https://doi.org/10.1016/j.atmosres.2021.105509

Albrecht, R. I., Goodman, S. J., Buechler, D. E., Blakeslee, R. J., \& Christian, H. J. (2016). Where Are the Lightning Hotspots on Earth? Bulletin of the American Meteorological Society, 97(11), 2051-2068. https://doi.org/10.1175/BAMS-D-14-00193.1

Ayugi, B., Zhidong, J., Zhu, H., Ngoma, H., Babaousmail, H., Rizwan, K., \& Dike, V. (2021). Comparison of CMIP6 and CMIP5 Models in Simulating Mean and Extreme Precipitation over East Africa. https://doi.org/10.20944/PREPRINTS202102.0111.V1

Barnett, E. (2013, January 17). Lethal weather on 'world's most dangerous lake. CNN. https://edition.cnn.com/2013/01/17/world/africa/lake-victoria-weather-deaths/index.html

Cannon, T., Schipper, L., Bankoff, G., \& Krüger, F. (2014). World Disasters Report: Focus on culture and risk. International Federation of Red Cross and Red Crescent Societies. https://www.ifrc.org/Global/Documents/Secretariat/201410/WDR 2014.pdf

Chai, T., \& Draxler, R. R. (2014). Root mean square error (RMSE) or mean absolute error (MAE)? - Arguments against avoiding RMSE in the literature. Geoscientific Model Development, 7(3), 1247-1250. https://doi.org/10.5194/gmd-7-1247-2014

Cinner, J. E., Huchery, C., Hicks, C. C., Daw, T. M., Marshall, N., Wamukota, A., \& Allison, E. H. (2015). Changes in adaptive capacity of Kenyan fishing communities. Nature Climate Change, 5(9), 872-876. https://doi.org/10.1038/nclimate2690

Darwall, W., Smith, K., Lowe, T., \& Vié, J.-C. (2005). The Status and Distribution of Freshwater Biodiversity in Eastern Africa. In IUCN SSC Freshwater Biodiversity Assessment Programme (p. viii + 36). IUCN, Gland, Switzerland and Cambridge, UK. https://bit.ly/3sycTE8

Diaconescu, E. P., Gachon, P., \& Laprise, R. (2015). On the Remapping Procedure of Daily Precipitation Statistics and Indices Used in Regional Climate Model Evaluation. Journal of Hydrometeorology, 16(6), 2301-2310. https://doi.org/10.1175/JHM-D-15-0025.1

Dinku, T., Funk, C., Peterson, P., Maidment, R., Tadesse, T., Gadain, H., \& Ceccato, P. (2018). Validation of the CHIRPS satellite rainfall estimates over eastern Africa. Quarterly Journal of the Royal Meteorological Society, 144(S1), 292-312. https://doi.org/10.1002/qj.3244

Eyring, V., Bony, S., Meehl, G. A., Senior, C. A., Stevens, B., Stouffer, R. J., \& Taylor, K. E. (2016). Overview of the Coupled Model Intercomparison Project Phase 6 (CMIP6) experimental design and organization. Geoscientific Model Development, 9(5), 1937-1958. https://doi.org/10.5194/gmd-9-1937-2016

Finney, D. L., Marsham, J. H., Rowell, D. P., Kendon, E. J., Tucker, S. O., Stratton, R. A., \& Jackson, L. S. (2020). Effects of Explicit Convection on Future Projections of Mesoscale Circulations, Rainfall, and Rainfall Extremes over Eastern Africa. Journal of Climate, 33(7), 2701-2718. https://doi.org/10.1175/JCLI-D-19-0328.1

Gebrechorkos, S. H., Hülsmann, S., \& Bernhofer, C. (2019). Long-term trends in rainfall and temperature using high-resolution climate datasets in East Africa. Scientific Reports, 9(1), 11376. https://doi.org/10.1038/s41598-019-47933-8

Haarsma, R. J., Roberts, M. J., Vidale, P. L., Senior, C. A., Bellucci, A., Bao, Q., Chang, P., Corti, S., Fučkar, N. S., Guemas, V., von Hardenberg, J., Hazeleger, W., Kodama, C., Koenigk, T., Leung, L. R., Lu, J., Luo, J.-J., Mao, J., Mizielinski, M. S., ... von Storch, J.-S. (2016). High Resolution Model Intercomparison Project (HighResMIP v1.0) for CMIP6. Geoscientific 
Model Development, 9(11), 4185-4208. https://doi.org/10.5194/gmd-9-4185-2016

Hamilton, S., Munyaho, A. T., Krach, N., \& Glaser, S. (2016). Bathymetry TIFF, Lake Victoria Bathymetry, raster, 2017, V7. Harvard Dataverse. https://doi.org/https://doi.org/10.7910/DVN/SOEKNR

Kundzewicz, Z. W., Kanae, S., Seneviratne, S. I., Handmer, J., Nicholls, N., Peduzzi, P., Mechler, R., Bouwer, L. M., Arnell, N., Mach, K., Muir-Wood, R., Brakenridge, G. R., Kron, W., Benito, G., Honda, Y., Takahashi, K., \& Sherstyukov, B. (2014). Flood risk and climate change: global and regional perspectives. Hydrological Sciences Journal, 59(1), 1-28. https://doi.org/10.1080/02626667.2013.857411

Mafaranga, H. (2020). Heavy Rains, Human Activity, and Rising Waters at Lake Victoria. Eos, 101. https://doi.org/10.1029/2020EO146582

Ngoma, H., Wen, W., Ayugi, B., Babaousmail, H., Karim, R., \& Ongoma, V. (2021). Evaluation of precipitation simulations in CMIP6 models over Uganda. International Journal of Climatology, joc.7098. https://doi.org/10.1002/joc.7098

Nicholson, S. E. (2017). Climate and climatic variability of rainfall over eastern Africa. Reviews of Geophysics, 55(3), 590-635. https://doi.org/10.1002/2016RG000544

Njiru, M., Kazungu, J., Ngugi, C. C., Gichuki, J., \& Muhoozi, L. (2008). An overview of the current status of Lake Victoria fishery: Opportunities, challenges and management strategies. Lakes \& Reservoirs: Research \& Management, 13(1), 1-12. https://doi.org/10.1111/j.14401770.2007.00358.x

O’Neill, B. C., Tebaldi, C., van Vuuren, D. P., Eyring, V., Friedlingstein, P., Hurtt, G., Knutti, R., Kriegler, E., Lamarque, J.-F., Lowe, J., Meehl, G. A., Moss, R., Riahi, K., \& Sanderson, B. M. (2016). The Scenario Model Intercomparison Project (ScenarioMIP) for CMIP6. Geoscientific Model Development, 9(9), 3461-3482. https://doi.org/10.5194/gmd-9-34612016

Ogega, O. M., Koske, J., Kung'u, J. B., Scoccimarro, E., Endris, H. S., \& Mistry, M. N. (2020). Heavy precipitation events over East Africa in a changing climate: results from CORDEX RCMs. Climate Dynamics, 55(3-4), 993-1009. https://doi.org/10.1007/s00382-020-05309-z

Ridder, N. N., Pitman, A. J., \& Ukkola, A. M. (2021). Do CMIP6 Climate Models Simulate Global or Regional Compound Events Skillfully? Geophysical Research Letters, 48(2). https://doi.org/10.1029/2020GL091152

Roussi, A. (2019). Gigantic Nile dam prompts clash between Egypt and Ethiopia. Nature, 574(7777), 159-160. https://doi.org/10.1038/d41586-019-02987-6

Rzóska, J. (1976). Lake Victoria, Physical Features, General Remarks on Chemistry and Biology (pp. 167-175). https://doi.org/10.1007/978-94-010-1563-9_21

Sayer, C. A., Máiz-Tomé, L., \& Darwall, W. R. T. (2018). Freshwater biodiversity in the Lake Victoria Basin: Guidance for species conservation, site protection, climate resilience and sustainable livelihoods. IUCN, International Union for Conservation of Nature. https://doi.org/10.2305/IUCN.CH.2018.RA.2.en

Scheffers, B. R., De Meester, L., Bridge, T. C. L., Hoffmann, A. A., Pandolfi, J. M., Corlett, R. T., Butchart, S. H. M., Pearce-Kelly, P., Kovacs, K. M., Dudgeon, D., Pacifici, M., Rondinini, C., Foden, W. B., Martin, T. G., Mora, C., Bickford, D., \& Watson, J. E. M. (2016). The broad footprint of climate change from genes to biomes to people. Science, 354(6313), aaf7671. https://doi.org/10.1126/science.aaf7671

Scoccimarro, E., Gualdi, S., Bellucci, A., Zampieri, M., \& Navarra, A. (2016). Heavy precipitation events over the Euro-Mediterranean region in a warmer climate: results from CMIP5 models. 
Regional Environmental Change, 16(3), 595-602. https://doi.org/10.1007/s10113-014-0712$\mathrm{y}$

Seehausen, O. (2002). Patterns in fish radiation are compatible with Pleistocene desiccation of Lake Victoria and 14600 year history for its cichlid species flock. Proceedings of the Royal Society of London. Series B: Biological Sciences, 269(1490), 491-497. https://doi.org/10.1098/rspb.2001.1906

Senay, G. B., Velpuri, N. M., Bohms, S., Demissie, Y., \& Gebremichael, M. (2014). Understanding the hydrologic sources and sinks in the Nile Basin using multisource climate and remote sensing data sets. Water Resources Research, 50(11), 8625-8650. https://doi.org/10.1002/2013WR015231

Stehfest, E., van Zeist, W.-J., Valin, H., Havlik, P., Popp, A., Kyle, P., Tabeau, A., Mason-D’Croz, D., Hasegawa, T., Bodirsky, B. L., Calvin, K., Doelman, J. C., Fujimori, S., Humpenöder, F., Lotze-Campen, H., van Meijl, H., \& Wiebe, K. (2019). Key determinants of global land-use projections. Nature Communications, 10(1), 2166. https://doi.org/10.1038/s41467-01909945-W

Stokstad, E. (2016). Power play on the Nile. Science, 351(6276), 904-907. https://doi.org/10.1126/science.351.6276.904

Sutcliffe, J. V, \& Petersen, G. (2007). Lake Victoria: derivation of a corrected natural water level series / Lac Victoria: dérivation d'une série naturelle corrigée des niveaux d'eau. Hydrological Sciences Journal, 52(6), 1316-1321. https://doi.org/10.1623/hysj.52.6.1316

Sutcliffe, John V. (2009). The Hydrology of the Nile Basin (pp. 335-364). https://doi.org/10.1007/978-1-4020-9726-3_17

Taabu-Munyaho, A., Marshall, B., Tomasson, T., \& Marteinsdottir, G. (2016). Nile perch and the transformation of Lake Victoria. African Journal of Aquatic Science, 41(2), 127-142. https://doi.org/10.2989/16085914.2016.1157058

Thiery, W., Davin, E. L., Seneviratne, S. I., Bedka, K., Lhermitte, S., \& van Lipzig, N. P. M. (2016). Hazardous thunderstorm intensification over Lake Victoria. Nature Communications, 7(1), 12786. https://doi.org/10.1038/ncomms12786

Tungaraza, C. (2012). Long-term climate impact on the Lake Victoria region influences water level fluctuation and resource availability. International Journal of Environmental Sciences, 2(3). https://doi.org/10.6088/ijes.00202030055

UNEP (2006). Lake Victoria Basin Environment Outlook: Environment and Development. https://bit.ly/3kXwiKV

UNESCO (1995). Discharge of selected rivers in Africa. In Studies and reports in hydrology (p. 166). United Nations Educational, Scientific, and Cultural Organization (UNESCO). https://bit.ly/35KbvEj

van Zwieten, P. A. M., Kolding, J., Plank, M. J., Hecky, R. E., Bridgeman, T. B., MacIntyre, S., Seehausen, O., \& Silsbe, G. M. (2016). The Nile perch invasion in Lake Victoria: cause or consequence of the haplochromine decline? Canadian Journal of Fisheries and Aquatic Sciences, 73(4), 622-643. https://doi.org/10.1139/cjfas-2015-0130

Vanderkelen, I., van Lipzig, N. P. M., \& Thiery, W. (2018). Modelling the water balance of Lake Victoria (East Africa) - Part 2: Future projections. Hydrology and Earth System Sciences, 22(10), 5527-5549. https://doi.org/10.5194/hess-22-5527-2018

Wainwright, C. M., Marsham, J. H., Keane, R. J., Rowell, D. P., Finney, D. L., Black, E., \& Allan, R. P. (2019). 'Eastern African Paradox' rainfall decline due to shorter not less intense Long Rains. Npj Climate and Atmospheric Science, 2(1), 1-9. https://doi.org/10.1038/s41612-019- 


\section{1-7}

Willmott, C., \& Matsuura, K. (2005). Advantages of the mean absolute error (MAE) over the root mean square error (RMSE) in assessing average model performance. Climate Research, 30, 79-82. https://doi.org/10.3354/cr030079

World Bank Group (2016). Reviving Lake Victoria by Restoring Livelihoods. https://www.worldbank.org/en/news/feature/2016/02/29/reviving-lake-victoria-byrestoring-livelihoods

World Bank. (2018). Lake Victoria Environmental Management Project: Project Information Document/Integrated Safeguards Data Sheet (PID /ISDS). The World Bank, 21. https://bit.ly/3zzQB8n

Wu, Z., Huang, N. E., Long, S. R., \& Peng, C.-K. (2007). On the trend, detrending, and variability of nonlinear and nonstationary time series. Proceedings of the National Academy of Sciences, 104(38), 14889-14894. https://doi.org/10.1073/pnas.0701020104

Zhou, R.-G., Hu, W., Fan, P., \& Ian, H. (2017). Quantum realization of the bilinear interpolation method for NEQR. Scientific Reports, 7(1), 2511. https://doi.org/10.1038/s41598-01702575-6 